\title{
建筑工程造价超预算原因及其控制的探讨
}

郡立强

山东滨化集团股份有限公司

DOI:10.32629/btr.v2i1.1762

[摘 要] 建筑工程造价预算由于受到自然因素、人为因素以及社会因素的影响, 导致建筑工程造价超预算现象, 并且一般建筑 工程造价允许出现合理范围内的造价超预算, 但是如果超预算差价额较大, 就会损害项目工程经济效益, 因此为了保障建筑项 目工程的经济效益, 本文阐述了建筑工程造价超预算控制的重要性,对建筑工程造价超预算产生的原因及其控制策略进行了探 讨分析。

[关键词] 建筑工程造价；预算控制；重要性；超预算；原因；控制策略

建筑工程造价超预算控制工作可以节约资源, 降低成本, 如果建筑工程造价预算不合理, 最终会影响企业的施工结算, 甚至于引发经济纠纷, 基于此, 以下就建筑工程造价超预算 产生的原因及其控制策略进行了探讨分析。

\section{1 建筑工程造价预算控制的重要性分析}

建筑工程造价工作对于提高建筑项目工程的经济效益 具有重要作用, 并且工程造价有效控制以及合理的预算, 不 仅能够保障建筑工程项目顺利进行施工的同时, 还能够很好 的避免因为造价控制不合理所造成的建筑工程项目质量问 题、设计方案不合规范的问题以及防止项目在建设过程当中 的返工问题。对建筑工程造价进行合理预算以及有效控制, 还 可以提高建筑项目的施工进度, 从而缩短工期, 为建筑企业提 升经济效益。而且对于建筑工程造价预算的有效控制, 不仅能 够合理利用工程项目中的可用资金, 还能够为建筑企业节约 建设成本, 提升企业的市场竞争能力, 从而增加企业的经济 利润。同时对于建筑工程造价预算的有效控制, 还能够保障 建筑项目工程的施工方向, 使得施工作业有目的地以及有序 进行, 从而避免了施工建设过程中的盲目性, 以及在施工过 程当中资金周转中资金的流失与不必要的浪费。

\section{2 建筑工程造价超预算产生的主要原因分析}

建筑工程造价超预算产生的原因有很多, 结合笔者实践 工作经验, 认为主要包括:

2.1 概预算编制原因。编制工程预算时预算编制人员没 有对工程的实际情况进行深入的调查以及研究, 致使编制出 来的建筑工程预算价格存在着漏项以及缺项等差错, 进而不 能全面细致地反映与正确预测出建筑工程实际施工过程中 需要的费用支出状况。因此缺乏合理性以及科学性的工程预 算不能在实际建筑施工过程中发挥其指导意义。

2.2 材料市场价格不稳定原因。建筑工程建设一般周期 较长、工序复杂、涉及范围广, 所以建筑工程在材料价格预 算方面要有一定的预留空间。在建筑工程的材料市场中, 价 格波动受市场的影响较大, 而市场波动的风险也是较大, 因 此, 建筑工程所需的材料受市场波动, 在价格方面波动较大。 因此, 材料市场价格的不稳定性是建筑工程造价超预算的重
要原因之一。工程造价人员在进行材料预算时, 根据市场波 动进行预算, 但还是无法准确无误的进行预算。建筑工程在 施工过程中需要的建筑材料多以及机械设备多, 而这些都是 受市场波动影响较大。因此, 在编制造价预算时, 虽然给出的 预算方案不会出错, 但是施工过程中, 如果市场出现大幅上 涨, 同样会造成建筑工程超预算的情况。

2.3 工程变更原因。建筑工程施工过程中的很多不可预 见因素, 也会增加工程预算。例如, 由于地质资料所反映出来 的通常是局部地区的地质状况, 而实际开挖后, 发现地质条 件不能够满足设计的要求, 必须要改变基础或者加深基础; 在 钻孔桩或者挖孔桩的过程中经常会遇到流泥、流沙、溶洞以 及岩层等; 另外, 滑坡处理、基坑排水以及地下障碍物的拆除 等也会使建筑工程的造价预算增加, 这些问题都难以准确的 预计。

2.4 预算人员原因。由于专业素质和专业能力的个人差 异, 多数预算人员在工作时会出现不同程度的预算不合理现 象, 导致预算数额与实际造价有不同程度的差异出现, 最终 延缓建筑工程项目的实施速度和竣工日期。除此之外, 引起 超预算现象的另一重要原因是预算人员常常忽视工程预算 的重要性, 这方面主要表现为多数预算人员在没有实地考察 建筑工程项目或者没有经过详细的分析的前提下, 仅仅依靠 过去的相关预算经验开展建筑工程项目的预算, 从而引起超 预算现象发生。

\section{3 建筑工程造价超预算控制策略的分析}

3.1 科学编制工程造价预算

3.1.1 熟悉了解建筑工程的施工图纸, 对套用定额单价 以及工程量进行精确的计算, 在编制预算造价的过程中还要 对设计图纸进行反复的阅读, 直到真正领会了设计者的设计 意图, 把阅读图纸、熟悉工程以及审核图纸等过程充分结合 起来, 这样才能够做出比较准确的工程预算编制的分项, 并 计算出相应的工程量, 编制人员才能够对单价熟练套用, 进 而最大限度地避免产生错套、漏记以及重记等失误的出现。

3.1 .2 了解施工现场实际, 同时工程预算管理工作还要 对建筑工程施工组织的特点进行综合考虑, 然后在这个基础 
上开展预算编制工作, 在开展预算编制工作之前还要做好前 期的准备工作, 要注意收起建筑工程的勘察报告、施工设计 的图纸、各类标准图集以及地形测量相关图纸等有关的资料, 并深入到施工现场进行勘察与调查施工现场的环境, 然后对 建筑施工方案进行研究, 同时还要对现行的建筑工程的取费 标准、预算定额、材料预算价格以及统一工程量的计算规则 等有一个全面的了解。

3.1.3 客观分析价格因素, 给价差的调整留有足够的余 地。这主要是因为建筑工程建设需要的材料以及设备的品种 比较多并且价格多样, 设备及材料购置的费用在工程造价中 占据着较大的比例, 因此, 工程造价编制工作人员必须要对 材料设备的价格、性能、规格以及品种等有一个细致、全面 的了解。由于材料设备的价格标准是按照市场的价格来确定 的, 必须要对其实施差价调整, 做好动态管理工作极其重要。 要避免因为价格的波动而给超预算控制带来影响必须要建 立建筑工程造价差价的预测系统, 通过该系统来对各项工程 的造价指标当前的变化趋势进行合理的预测, 在这个基础上 对造价差价进行合理的调整。

3.2 充分考虑设备材料价格的变动。建筑工程规模大, 施 工周期长, 施工中设计的材料设备种类繁多, 由于市场经济变 化速度快, 设备材料价格波动大, 建筑工程造价预算控制工作 很难有效开展。这就需要建筑单位充分考虑材料设备的价格 变动, 深入市场, 了解价格规律, 造价预算与实际价格应该保 留一定的变动空间, 避免因价格变动导致超预算的产生。

3.3 严格项目工程变更控制。建筑工程通常需要经过规 划、设计以及实施这三个阶段, 但是在实际施工的过程中项 目设计经常会出现变更, 其中主要包括客观条件发生变化所 引发的变更、设计缺陷所引发的变更以及业主意愿引发的变 更等等, 工程项目出现变更就意味着工程造价的变化, 因此 工程实施前, 对工程造价进行主动、积极的控制是十分必要 的。而控制工程造价最有效的手段, 是技术与经济相结合, 克服长期以来技术与经济相分离的现象。即工程招标前, 造 价人员了解建设单位对工程的质量、工期、资金投入的情况, 综合考虑建设环境、建筑市场和建筑企业的各种因素, 第一 时间查看图纸问题, 向设计人员提出图纸不完善、不合理的
地方等等, 进而修正工程预算价, 尽可能减少项目实施后的 设计变更。如果出现变更, 预算控制工作人员还必须要对该 部分实施技术与经济论证, 对变更的可行性以及必要性进行 确认, 把设计变更所带来的造价超支降到最低。

3.4 不断提高预算人员素质。预算人员素质的高低是有 效控制过程造价关键。预算编制管理人员不仅要提高自身的 工程造价专业知识, 还需要学习相关的法规政策, 了解建筑 工程各项目的施工流程。另外, 预算编制管理人员还应该熟 悉建筑市场的需求, 市场经济对建筑工程造价控制有直接影 响, 合理控制工程造价超预算, 需要深入市场, 了解市场的变 动方向, 对建筑设备和材料的价格进行准确地预算。最后, 预算编制管理人员还应该熟悉各项目的施工工艺, 建设单位 应该加大对编制管理人员的培训力度, 聘请专家对编制管理 人员进行技能培训, 编制管理人员也应该积极主动地投入到 学习中去, 不断提升自己, 保障工程造价控制工作顺利开展。

\section{4 结束语}

综上所述, 为了保障建筑工程造价预算的有效性, 在建 筑工程造价预算过程中, 需要根据工程项目的施工图纸、施 工方案、工程量计算规则等进行, 并且全面准确收集相关材 料, 从而保障建筑工程的进度、质量、效益等。但是由于各 种因素的影响, 使其存在超预算的问题, 因此为了充分发挥 建筑工程造价预算的作用, 必须加强对建筑工程造价超预算 产生的原因及其控制策略进行分析。

\section{[参考文献]}

[1]许一友.建筑工程造价超预算的原因及控制对策分 析[J].低碳世界,2016(11):64.

[2]王真.探讨建筑工程造價超预算的原因及控制对策 [J].经济研究导刊,2017(36):24.

[3]高志朵.建筑工程造价超预算的原因及控制[J].建筑 与装饰,2017(06):36

[4]史向超.探析建筑安装工程造价超预算的原因及其措 施[J].装饰装修天地,2017(19):43。

[5]季慧莲.建设项目工程造价超预算原因分析及控制措 施[J].中国房地产业,2018(10):29. 